\title{
Genetic Analysis of Yield and its Attributes in Bread Wheat (Triticum Aestivum L. Em. Thell) Under Irrigated and Rainfed Conditions
}

Divya Chaudhary ( $\square$ divyachaudhary6767@gmail.com)

G B Pant University of Agriculture and Technology: Govind Ballabh Pant University of Agriculture \& Technology https://orcid.org/0000-0002-7704-0372

Swati

G B Pant University of Agriculture and Technology: Govind Ballabh Pant University of Agriculture \& Technology

Kuldeep Nagar

G B Pant University of Agriculture and Technology: Govind Ballabh Pant University of Agriculture \& Technology

Richa Dhyani

G B Pant University of Agriculture and Technology: Govind Ballabh Pant University of Agriculture \& Technology

\section{Research Article}

Keywords: Wheat, gca, sca, irrigated and rainfed, Line X Tester, G X E interaction

Posted Date: December 13th, 2021

DOI: https://doi.org/10.21203/rs.3.rs-1010087/v1

License: () (1) This work is licensed under a Creative Commons Attribution 4.0 International License. Read Full License 


\section{Abstract}

Experiments were conducted to study the genetics and combining ability for yield and its attributes under Irrigated (E1) and Rainfed (E2) conditions using F1 hybrids derived from Line X Tester mating design by crossing eleven lines with three testers. Significant differences were observed among all the genotypes for all the traits in both E1 and E2 environments as well as in pooled analysis. The $\sigma^{2} \mathrm{gca} / \sigma^{2} \mathrm{sca}$ ratio indicated predominance of non-additive gene action for all the characters in both environments. Therefore, this component of variance can be utilize in breeding programme through exploitation of heterosis and the selection process for identification of superior plant type should be postponed to further generations like F4 or F5. VL3001 and KACHU*2//WHEAR/SOKOLL was identified as good general combiner in irrigated condition (E1) and in rainfed condition (E2), respectively for maximum number of traits. Parent VL3001 was also identified as good general combiner for maximum number of traits in case of pooled analysis. Cross BECARD/KACHU $\times$ WH1080, BOW/VEE/5/ND/VG9144//KAL/BBB/YACO/4/CHIL/6/CASKOR/3/... $\times$ WH1080 and C306 $\times$ WH1142 was identified as good specific combination for maximum number of traits in irrigated condition (E1), rainfed condition (E2) and in pooled analysis, respectively.

\section{Introduction}

Wheat (Triticum aestivum L. em. Thell) is an allohexaploid $(2 n=6 x=42)$ self-pollinated annual plant having global significance which belongs to Graminae (Poaceae) family, tribe Triticeae and of the genus Triticum. It is a staple food crop of more than one third of world population because it supplies $20 \%$ food calories to growing population in the world. Wheat grain contains $70 \%$ carbohydrates, $22 \%$ crude fibres, $12 \%$ protein, $12 \%$ water, $2 \%$ fat and $1.8 \%$ minerals (Noorka et al., 2013). The major wheat producing countries are China, India, USA, France, Russia, Canada, Australia, Pakistan etc. Wheat has been described as the 'King of cereals' because of acreage it occupies, high productivity and world trade of this crop is greater in comparison to all other crops combined. The wheat crop, in the world, occupy rank first in terms of area (216.00 Mha) and second in terms of production (692.25 Mt) and yield is (28.55 q/ha) (USDA, 2018). India is second largest producer of wheat after China. An effective breeding strategies need to be developed for maximum improvement in the genetic yield potential of wheat. In order to evolve an effective hybridization programs in wheat which is a self -pollinated crop, there is a need to develop such strategy which allows the accumulation of fixable gene effects in a homozygous line. In order to exploit different types of gene action present in the population, information regarding magnitude of genetic variance and combining ability for important traits is essential. Combining ability analysis is an important tool for the selection of superior parents, because the success of an effective breeding programme is depending on the choice of parents and it also provides the information regarding the nature and magnitude of gene effects controlling quantitative traits. The line $x$ tester technique, developed by Kempthorne (1957) is used to estimate, in both self and cross pollinated field crops, combining ability and gene effects for understanding the nature of gene action involved in the expression of quantitative traits. In the formulation of system breeding project for rapid improvement, this technique provide a guide line for selection of superior parents and desirable cross combinations.

In the world, 70\% of the wheat is cultivated under rain-fed conditions (Raza et al., 2018), which may increase further due to climate changes. Even the irrigated wheat cultivating areas are predictable to experience water scarcity, therefore the development of wheat varieties having good water-use efficiency and/or drought tolerance a priority research area for wheat breeders. Drought stress is one of the main limiting factors for wheat yield in the semi-arid regions of the world. Accordingly, for sustainable production of wheat crop, it is highly important to identify the wheat cultivars and lines which have high yield in stress-free conditions as well as acceptable yield in moisture stress condition. Water deficiency affect to various growth and development stages (vegetative, reproductive, and grain development) and has a negative impact on the physiological processes of the plant, consequently affecting yield as well (Mursalova et al., 2015). The relationship between the morpho-physiological traits associated with tolerance to rainfed condition is very much important in selection criteria for drought tolerance. The effect of water stress depends on the plant growth stage and may affect potential yield and yield components. Drought stress can reduce grain yield, and due to this stress, 17-70\% loss in average grain yield has been estimated (Nouri-Ganbalani et al., 2009). Morphological traits, such as number of grains per spike, productive tillers per plant, 1000 grain weight, peduncle length, spike length, plant height, and grain weight per spike influence the tolerance of wheat to moisture stress condition (Sattar et al., 2018). Therefore, grain yield and its components are two important selection criteria in arid regions.

\section{Material And Methods}

Eleven lines of wheat, BECARD/KACHU, BOW/VEE/5/ND/VG9144//KAL/BBB / YACO/4/CHIL/6/CASKOR/3/..., 92.001E7.32.5/SLVS/5/NS732/HER/3/PRL/SARA//TSI/ VEE\#5/..., FRANCOLIN\#1/BAJ\#1, KACHU*2//WHEAR/SOKOLL, PRL/2*PASTOR // PBW343*2/KUKUNA/3/ROLF07/4/BERKUT//..., UP2572, VL3001, NW5054, PBW644, C306 (female parents) were crossed with three testers WH1080, WH1142, HD3086. The F1 seeds of the thirty-three crosses along with their parents and two checks HD2967 and PBW660 were evaluated in randomized complete block design with three replications in irrigated (E1) and rainfed (E2) conditions. Each plot consisted of 2 rows of $1 \mathrm{~m}$ length with a row to row and plant to plant distance of $20 \mathrm{~cm}$ or $23 \mathrm{~cm}$ and $10 \mathrm{~cm}$, respectively. The proposed research work has been conducted in Norman E. Borlaug Crop Research Centre of Govind Ballabh Pant University of Agriculture and Technology, Pantnagar during the Rabi, 2016-2017 and Rabi, 2018-2019. Climate wise, Pantnagar falls in the humid subtropical zone having miscellaneous type of soil texture, which is generally 1.0-1.5 m deep. High water table, shallow depth and calcareous nature are the key features of the soil in this area. Only single irrigation was applied at tillering stage, after that no irrigation was applied to keep the experiment under moisture stress. Five plants at random of all genotypes were used to record biometrical observations viz., days to $75 \%$ heading, days to maturity, plant height $(\mathrm{cm})$, peduncle length $(\mathrm{cm})$, awn length $(\mathrm{cm})$, tillers per plant, flag leaf area $\left(\mathrm{cm}^{2}\right)$, spike length $(\mathrm{cm})$, spikelets per spike, grains per spike, grain weight per spike (g), 1000 grain weight $(\mathrm{g})$, biological yield per plant $(\mathrm{g})$, grain yield per plant $(\mathrm{g})$ and harvest index. The mean value of each trait over the replication was used for statistical analysis. The data of each environment was analysed separately and pooled analysis over the environments also carried out. The recorded data subjected to analysis of variance and line $x$ tester combining ability analysis studied in above genotypes as described by Kempthorne (1957).

\section{Results And Discussion}




\section{Analysis of variance}

The mean performance and analysis of variance indicated that all the genotypes differ significantly for all the traits in both environments, as well as in pooled analysis. Polled analysis of variance revealed that the environmental differences were statistically significant for all the traits except awn length and grain weight per spike. The differences due to pooled analysis among the wheat genotypes were statistically significant for plant height, peduncle length, spike length, awn length, spikelets per spike, flag leaf area, 1000 grain weight and it was non-significant for days to $75 \%$ heading, days to maturity, tillers per plant, grains per spike, grain weight per spike, grain yield per plant and harvest index. The mean squares due to genotype $x$ environment (G $x \mathrm{E})$ interactions were significant for all the traits except peduncle length, indicate the major contribution of $\mathrm{G} X \mathrm{E}$ interaction than genotypic component in the expression of these traits. The significant mean square due to genotype, environment and G X E for plant height, spike length, spikelets/spike, flag leaf area and 1000 grain weight suggested the importance of both genotype and environment components for these traits. Therefore, inference of the present study and also the previous work (Ahmed et al., 2007 and Almeselmani et al., 2011)revealed that the high yielding wheat genotypes with water stress tolerance cannot simply developed by crossing between the water stress tolerant and high yielding genotypes without referring to environmental effect.

\section{Analysis of variance for combining ability}

The analysis of variance for combining ability was performed for fifteen yield and its contributing traits in irrigated (E1) and rainfed (E2) conditions. The mean squares due to crosses were partitioned into mean squares due to testers, due to lines and line $\mathrm{x}$ tester interaction components. The mean square due to lines were significant for ten characters in E1, days to $75 \%$ heading, days to maturity, plant height, spike length, peduncle length, awn length, tillers per plant, 1000 grain weight, grain weight per spike and biological yield per plant. In E2, ten characters exhibited significant mean squares namely days to $75 \%$ heading, plant height, spike length, peduncle length, awn length, spikelets per spike, flag leaf area $\left(\mathrm{cm}^{2}\right), 1000$ grain weight, grain yield per plant and biological yield per plant.

Mean squares due to testers were significant for five characters namely plant height, spike length, spikelets per spike, flag leaf area ( $\mathrm{cm}^{2}$ ) and grains per spike in E1, while in E2 conditions four characters viz. spike length, awn length, spikelets per spike and flag leaf area $\left(\mathrm{cm}^{2}\right)$.

Mean squares due to line $x$ tester interaction were found to be significant for all fifteen characters namely days to $75 \%$ heading, days to maturity, plant height, spike length, peduncle length, awn length, tillers per plant, spikelets per spike, flag leaf area $\left(\mathrm{cm}^{2}\right), 1000$ grain weight, grain weight per spike, grain yield per plant, grains per spike, biological yield per plant and harvest index in E1 and twelve characters in E2 namely days to $75 \%$ heading, plant height, peduncle length, awn length, spikelets per spike, flag leaf area $\left(\mathrm{cm}^{2}\right), 1000$ grain weight, grain weight per spike, grain yield per plant, grains per spike, biological yield per plant and harvest index.

Higher magnitude of line $x$ tester component than either due to lines or testers indicated the predominant role of non-additive gene action (dominance). The results from the present study revealed that line $x$ tester interaction are significant for most of the traits in both environments. Line $x$ tester interaction is far more important than line or tester alone in deciding the hybrid performance. Similar findings were also reported by Srivastava et al., (2012) and Farooq et al., (2019).

\section{Variance components of combining ability}

In irrigated condition, highest general combining ability variance $\left(\sigma^{2} \mathrm{gca}\right)$ was observed for biological yield per plant followed by plant height. Rest of the characters showed relatively smaller amount of $\sigma^{2}$ gca. However, in rainfed condition, highest gca variance was observed for harvest index followed by biological yield / plant while rest of the characters showed relatively smaller amount of $\sigma^{2}$ gca. In irrigated condition, maximum variance for specific combing ability ( $\left.\sigma^{2} s c a\right)$ was observed for the trait biological yield per plant followed by harvest index. The estimate of $\sigma^{2}$ gca $/ \sigma^{2}$ sca indicated predominance of nonadditive gene action for all the characters. However, in rainfed condition, maximum $\sigma^{2}$ sca was observed for the trait grains per spike followed by biological yield / plant. The estimates of $\sigma^{2} \mathrm{gca} / \sigma^{2}$ sca indicate predominance of non-additive gene action for yield and its contributing characters condition as in E1. Results presented by Rajesh et al., (2002), Majeed et al., (2011), Srivastava et al., (2012) and Farooq et al., (2019) also indicated preponderance of nonadditive gene effects in the expression for grain yield and its attributes.

Considering the above results, it may be concluded that there was predominant role of non-additive gene action in the inheritance of all the traits in both irrigated and rainfed condition. The most efficient way for utilizing the non-additive genetic variance is through the exploitation of heterosis and the selection process for identification of superior plant type should be postponed to further generations like F4 or F5. Since it was observed that sca was the predominant contributor to genetic variance, thus, it is suggested that selection of sca is likely to be the most effective method to exploit hybrid vigour.

\section{Estimates of combining ability effect}

In combining ability effects, the general combining ability (gca) effect represent the additive gene action and specific combining ability (sca) effects represent the non- additive gene action interactions. The non-additive gene effects contribute in the improvement of grain yield in self-pollinated crops by the commercial exploitation of heterosis. In self-pollinated crops, however, the additive $x$ additive type of interaction is also feasible in later generations and can be exploited for the improvement of grain yield and its attributes. The results of gca effect of parentes and sca effect of all cross combinations are given in Table1 and 2 .

In irrigated condition (E1), VL3001 was identified as good general combiner for maximum number (nine) of traits viz., plant height, peduncle length, awn length, spikelets per spike, flag leaf area, grain weight/spike, grain yield/plant, grains/spike, biological yield/plant followed by FRANCOLIN\#1/BAJ\#1 and WH1142 for eight traits. FRANCOLIN\#1/BAJ\#1 was identified as good general combiner for days to $75 \%$ heading, days to maturity, plant height, peduncle

Page 3/10 
length, awn length, flag leaf area, 1000 grain weight and harvest index while, WH1142 was a good general combiner for spike length, peduncle length, awn length, spikelets per spike, flag leaf area, grain yield/plant, grains/spike and biological yield/plant.In rainfed condition (E2), KACHU*2//WHEAR/SOKOLL, FRANCOLIN \#1/BAJ\#1 and VL3001 were identified as good general combiner for maximum number (seven) of traits. KACHU*2//WHEAR/SOKOLL was identified as a good general combiner for plant height, spike length, peduncle length, spikelets per spike, flag leaf area, grain weight/spike, grains/spike, whereas, FRANCOLIN \#1/BAJ\#1 for days to 75\% heading, awn length, productive tillers/plant, spikelets per spike, flag leaf area, grains/spike and harvest index, VL3001 was good for days to maturity, plant height, peduncle length, flag leaf area, 1000 grain weight, grain yield/plant and harvest index.VL3001 was identified as a good general combiner for maximum number (nine) traits in pooled condition viz., plant height, peduncle length, spikelets per spike, flag leaf area, grain weight/spike, grain yield/plant, grains/spike, biological yield/plant and harvest index followed by BOW/VEE/5/ND/VG9144//KAL/ $\mathrm{BBB} / \mathrm{YACO} / 4 / \mathrm{CHIL} / 6 / \mathrm{CASKOR} / 3 / .$. for days to $75 \%$ heading, days to maturity, spikelets per spike, flag leaf area, 1000 grain weight, grain weight per spike and grains per spike and FRANCOLIN\#1/BAJ\#1 for days to $75 \%$ heading, days to maturity, plant height, peduncle length, awn length, flag leaf area and harvest index.

In specific combining ability, cross BECARD/KACHU $\times$ WH1080 appeared as good specific combination for maximum number (eight) of traits viz., plant height, spike length, peduncle length, awn length, productive tillers per plant, grain yield per plant, grains per spike, biological yield per plant followed by KACHU*2//WHEAR/SOKOLL $\times$ WH1080 for days to 75\% heading, awn length, productive tillers/plant, spikelets/spike, grain yield per plant biological yield per plant and harvest index and $\mathrm{C} 306 \times \mathrm{WH} 1142$ for spike length, peduncle length, awn length, flag leaf area, grain weight per spike, grains per spike and biological yield per plant in irrigated condition (E1). In rainfed condition (E2) BOW/VEE/5/ND/VG9144//KAL/BBB/YACO/ 4/CHIL /6/CASKOR/3/... $\times$ WH1080 was identified as good specific combination for maximum number (eight) of traits viz., spike length, productive tillers per plant, flag leaf area, 1000 grain weight, grain weight per spike, grain yield per plant, grains per spike and biological yield per plant followed by VL3001 $\times$ WH1080 for days to $75 \%$ heading, productive tillers per plant, flag leaf area, 1000 grain weight, grain yield per plant, grains per spike and biological yield per plant, $\mathrm{C} 306 \times \mathrm{WH} 1142 \mathrm{for}$ days to $75 \%$ heading, spike length, peduncle length, productive tillers/plant, spikelets/spike, grain weight per spike and biological yield per plant. In pooled analysis, C306 $\times$ WH1142 was identified as good specific combination for maximum number (nine) of traits viz., spike length, peduncle length, awn length, productive tillers/plant, spikelets/spike, flag leaf area, grain weight per spike, grains per spike and biological yield per plant followed by BECARD/KACHU $\times$ WH1080 for plant height, spike length, awn length, grain weight per spike, grains per spike, biological yield per plant and harvest index, cross

BOW/VEE/5/ND/VG9144//KAL/BBB/YACO/4/CHIL/6/CASKOR/3/... $\times$ WH1080 for days to maturity, spike length, productive tillers per plant, flag leaf area, 1000 grain weight, grains per spike and biological yield per plant.

The results for gca and sca effects were also close conformation with the observation of Mandal and Madhuri (2016) and Ishaq et al., (2018) for days to 75\% heading; for days to maturity with the observation of Singh et al., (2013), Pawar et al., (2014), Mandal and Madhuri (2016) and Ishaq et al., (2018); for plant height with the observation of Khan et al., (2007), Saxena and Rawat (2011), Hei et al., (2016) and Parveen et al., (2018); for spike length observation of Srivastava et al., (2012), Barot et al., (2013) Mandal and Madhuri (2016), Kumar et al., (2017) and Farooq et al., (2019); observation of Saxena and Rawat (2011) and Padhar et al. (2013) for peduncle length; Khan et al., (2007), Barot et al., (2013), Mandal and Madhuri (2016), Parveen et al., (2018) and Patel et al., (2018) for productive tillers/plant; for spikelets per spike with the observation of Saxena and Rawat (2011), Abro et al., (2016) and Kumar et al., (2017); for flag leaf area with the observation of Ahmed et al., (2017), Parveen et al., (2018), Sattar et al., (2018) and Farooq et al., (2019); for thousand grain weight Hei et al., (2016); Rani et al., (2017), Rajput and Kandalkar (2018) and Patel et al., (2018); by Çifcil and Yağdı1 (2010) and Ahmed et al., (2017) find similar observations for grains per spike; for grain weight per spike with the experiment of Çifcil and Yağdı1 (2010), Singh et al., (2013) and Kumar et al., (2017); by Khan et al., (2007), Singh et al., (2013), Padhar et al., (2013) and Ishaq et al., (2018) for biological yield per plant; Saxena and Rawat (2011), Barot et al., (2013), Ahmed et al., (2017) Parveen et al., (2018) and Rajput and Kandalkar (2018) for grain yield per plant and for harvest index by Padhar et al., (2013), Barot et al., (2013) and Devi et al., (2013).

The understanding of inheritance for various traits and identification of superior parentes are important pre-requisite for an effective breeding programme. The gca and sca effects are good measure of additive and non-additive gene action, respectively. This information about the nature of gene action in irrigated and water stress condition of the genotypes can help to determine an appropriate breeding strategy for yield improvement in wheat for water limited environment.

\section{Declarations}

\section{Acknowledgement}

The authors are thankful to Director, Experiment Station, GBPUAT, Pantnagar for providing the facilities to undertake the present study.

Author contributions Conceptualisation: S, DC. Data curation: DC. Formal analysis: DC, S. Methodology: DC, S. Project administration: S. Resources: DC, S, KN and RD. Supervision: S., Validation: S. Writing original draft: DC, S

\section{Ethical Statement for Solid State lonics}

Hereby, I Divya Chaudhary consciously assure that for the manuscript "Genetic Analysis of Yield and its Attributes in Bread Wheat (Triticum aestivum L. em. Thell) Under Irrigated and Rainfed Conditions" the following is fulfilled:

1) This material is the authors' own original work, which has not been previously published elsewhere.

2) The paper is not currently being considered for publication elsewhere.

3) The paper reflects the authors' own research and analysis in a truthful and complete manner. 
4) The paper properly credits the meaningful contributions of co-authors and co-researchers.

5) The results are appropriately placed in the context of prior and existing research.

6) All sources used are properly disclosed (correct citation). Literally copying of text must be indicated as such by using quotation marks and giving proper reference.

7) All authors have been personally and actively involved in substantial work leading to the paper, and will take public responsibility for its content.

\section{References}

1. Abro, S.A., Baloch, T.A., Baloch, M., Baloch, G.A., Baloch, T.A., Soomro, A.A., Jogi, Q. and Ali, M. 2016. Line $\times$ tester analysis for estimating combining ability in F1 hybrids of bread wheat. Pure Appl. Biol., 5(3):647-652.

2. Ahmed, M.D., Rizwan, M., Anwaar, H.A., Qadeer, A., Zafar, Z., Jamil, H. 2017. Combining ability analysis for morphological traits in wheat. International Journal of Biosciences, 11(4): 41-47.

3. Ahmed, N., Chowdhry, M.A., Khaliq, I., Maekawa, M., 2007. The inheritance of yield and yield components of five wheat hybrid populations under drought conditions. Indonesian. J. Agric. Sci., 8(2): 53-59.

4. Almeselmani, M., Abdullah, F., Hareri, F., Naaesan, M., Ammar, M.A., Kanbar, O.Z. and Saud, Abd., 2011. Effect of drought on different physiological characters and yield component in different Syrian durum wheat varieties. J Agric. Sci., 3: 127-133.

5. Barot, H.G. and Patel. M.S. 2013. Line x Tester analysis in bread wheat (Triticum aestivum L.). An International e-Journal, 2(4): $472-483$.

6. Çifcil, E. A. and Yağdı1, K. (2010). The research of the combining ability of agronomic traits of bread wheat in F1 and F2 generations. Journal of Agricultural Faculty of Uludag University, 24(2): 85-92.

7. Devi, E. L.; Swati; Singh, M.; Nagmakousar.; Goel, P.(2013) Genetic parameters and combining ability effects of parents for yield and yield contributing traits in bread wheat (Triticum aestivum L.). Asian Academic Research Journal of Multidisciplinary, 1(15): $226-237$.

8. Farooq, M.U., Ishaaq, I., Maqbool, R., Aslam, I., Naqvi, S.M.T.A. and Mustafa, S. 2019. Heritability, genetic gain and detection of gene action in hexaploid wheat for yield and its related attributes. Research article. AIMS Agriculture and Food, 4(1): 56-72.

9. Hei, N., Hussein, S., \& Laing, M. 2016. Heterosis and combining ability analysis of slow rusting stem rust resistance and yield and related traits in bread wheat. Euphytica, 207(3): 501-514.

10. ICAR-IIWBR 2018. Director's Report of AICRP on wheat and barley 2017-18, Ed: G.P. Singh. ICAR - Indian Institute of wheat and Barley Research, Karnal, Haryana, India. p: 2-3.

11. Ishaq, M., Ahmad, G., Afridi, K., Ali, M., Khan, T.U., Shah I.A., Ahmad, B., Ahmad, N., Ahmad, I., Saleem, A., Miraj, M. 2018. Combining ability and inheritance studies for morphological and yield contributing attributes through line $\mathrm{x}$ tester mating design in wheat (Triticum aestivum $\mathrm{L}$ ). Pure and Appled Biology, 7(1): 160-168.

12. Kempthorne, Q. 1957. An introduction to genetics statistics. John Willy \& Sons.Inc. NewYork. 468-471.

13. Khan, M.A., Ahmad, N., Akbar, M., Rehman, A. and Iqbal, M.M. 2007. Combining ability analysis in wheat. Pak. J. Agri. Sci., 44(1): 566-581.

14. Kumar, A., Biradar, S.S., Kimar, K.J.Y., Desai, S.A., Patel, B.N., Deepak, D.A., Arpitha, H.R. and Tigga, A. 2017. Studies on genetic variability and heritability for yield and yield attributing traits in advanced backcross segregating populations in bread wheat (Triticum aestivum L). 2017. International Journal of Current Microbiology and Applied Sciences, 6(10): 3664-3670.

15. Majeed, S., Sajjad, M. and Khan, S.H. 2011. Exploitation of non-additive gene actions of yield traits for hybrid breeding in spring wheat. J. of Agri. and social Sci., 7(4): 131-135.

16. Mandal, A.B., Madhuri, G. 2016. Combining ability analysis for morphological and yield traits in wheat (Triticum aestivum L.). Research article Journal of Plant Science and Research, 3(2): 1-4.

17. Mursalova, j., Akparov, Z., Ojaghi, J., Eldarov, M., Bellen, S., Gummadov, N., Morgounov, A. 2015. Evaluation of drought tolerance of winter bread wheat genotypes under drip irrigation and rainfed condition. Turkish Journal of Agriculture and Forestry, 39: 817-824.

18. Noorka, I. J., Batool, A., Sultan, S. A., Tabasum, S., Ali. A., 2013. Water stress Tolerance, Its Relationship to Stem Reserve Mobilization and Potence Ratio in Spring Wheat. . Amaerican Journal of Plant Science. 4(2): 27755.

19. Nouri-Ganbalani, A., Nouri-Ganbalani, G., Hassanpanah, D., 2009. Effect of drought stress condition on the yield and yield components of advanced wheat genotypes in Ardabil, Iran. Food Agric. Environ 7: 228-234.

20. Padhar, P.R., Chovatia, V.P., Jivani, L.L. and Dobriya, K.L. 2013. Combining ability analysis over environments in diallel crosses in bread wheat (Triticum aestivum L.). Int. J. of Agri. Sci., 9(1): 49-53.

21. Parveen, N., Kanwal, A., Amin, E., Shahzadi, F., Aleem, S., Tahir, M., Younas, A., Aslam, R., Aslam, N., Ghaffor, I., Makhdoom, M., Shakir, M.A., Najeebullad, M. 2018. Assessment of heritable variation and best combining genotypes for grain yield and its attributes in bread wheat. American Journal of Plant Science, 9: 1688-1698.

22. Patel, B.N., Desai, S.A., Rudranaik V., Biradar S.S., Arpitha, H.R., and Kumar, A. 2018. Combining ability analysis for yield and spot blotch disease resistance in tetraploid wheat. Int. J. Curr. Microbiol. App. Sci., 7(1): 1843-1847.

23. Pawar, K.K., Yadav, K.S., Bhaghel, S.K., Singh, A.K. 2014. Study of diallel analysis in bread wheat for grain yield and its component. Int. J. Sci. Res., 3: 6367. 
24. Rajesh, S., Bhawasar, R.C., Holkar, A.S., Verma, G.P., Patidar, G.L. and Prasad, S.V.S. 2002. Combining ability for grain yield and its components in wheat. Agric. Sci. Dig., 22(4): 273-275.

25. Rajput, R.H. and Kandalkar, V.S. 2018. Combining ability and heterosis for grain yields and its attributing traits in bread wheat (Triticum aestivum L). Journal of Pharmacology and Phytochemistry, 7(2): 113-119.

26. Rani, S., Swati, Joshi D., Goel, P., Ranjana, 2017. Genetic architecture of yield and some morphophysiological heat tolerance traits in Bread wheat. Int. J. Curr. Mcrobiol. Sci., 6(11): 2155-2165.

27. Raza, A., Khan, K., Anjum, M.M., Ali, A., Suktan, U., Ullah, S., Shah, Zubair. 2018. Evaluation of wheat lines for yield and yield components under rain-fed condition. Adv. Plants Agric. Res., 8(6): 400-404.

28. Sattar, S., Nawaz, B., Tahir, A., Ahmed, A., Naeem, M., Ghouri, M. Z., Jamshaid, M. 2018. Gene action and combining ability analysis of quantitative traits associated with grain yield in wheat under drought stress and normal irrigated conditions. Global Journal of Bio-Science and Biotechnology. 7 (4): $642-$ 650.

29. Saxena, P. and Rawat, R. S. (2011). Combining ability and heterosis for yield and quality traits in bread wheat (Triticum aestivum L. em. Thell). Pantnagar Journal of Research, 9(2): 170-177.

30. Singh K., Singh U.B. and Sharma S.N. 2013. Combining ability analysis for yield and its components in bread Wheat (Triticum aestivum L. em. Thell.). J. Wheat Res., 5(1): 63-67.

31. Srivastava, M. K., Singh, D. and Sharma, S. 2012. Combining ability and gene action for seed yield and its components in bread wheat [(Triticum aestivum) (L.) em.Thell]. Electronic Journal of Plant Breeding, 3(1): 606-611.

32. USDA, 2018. World and National area, production and productivity data available at site www.nass.usda.gov/publications/

\section{Tables}

Table 1: GCA effect of parentes under irrigated and rainfed conditions

\begin{tabular}{|c|c|c|c|c|c|c|c|c|c|}
\hline \multirow[t]{2}{*}{ S.N. } & \multirow[t]{2}{*}{ Parents } & \multicolumn{2}{|c|}{$\begin{array}{l}\text { Days to } 75 \% \\
\text { heading }\end{array}$} & \multicolumn{2}{|c|}{ Days to maturity } & \multicolumn{2}{|c|}{ Plant height (cm) } & \multicolumn{2}{|c|}{$\begin{array}{l}\text { Spike length } \\
\text { (cm) }\end{array}$} \\
\hline & & E1 & E2 & E1 & E2 & E1 & E2 & E1 & E2 \\
\hline 1 & BECARD/KACHU & -0.17 & 0.89 & -0.21 & 0.45 & $-10.33^{\star *}$ & $-3.63^{\star \star}$ & $-0.64^{\star *}$ & -1. \\
\hline 2 & BOW/VEE/5/ND/VG9144//KAL/BBB/YACO/4/CHIL/6/CASKOR/3/... & $-1.72 \star \star$ & $-5.89 * \star$ & $-1.5^{\star \star}$ & -0.10 & $8.62^{\star \star}$ & $7.28 * \star$ & 0.004 & $-0 .:$ \\
\hline 3 & 92.001E7.32.5/SLVS/5/NS-732/HER/3/PRL/SARA//TSI/VEE\#5/... & $0.72^{\star}$ & $-1.22 *$ & $-2.55^{\star \star}$ & -0.10 & $-1.14^{*}$ & 0.11 & -0.085 & $-0 .:$ \\
\hline 4 & FRANCOLIN\#1/BAJ\#1 & $-3.28 * \star$ & $-4.56 * \star$ & $-3.21 * \star$ & -0.55 & $-2.76 * \star$ & 0.13 & -0.25 & $0 . \mathrm{C}$ \\
\hline 5 & KACHU*2//WHEAR/SOKOLL & $3.72 \star \star$ & 0.11 & $2.45^{\star \star}$ & -0.10 & $-10.65^{\star \star}$ & $-6.83^{\star \star}$ & $0.46^{\star *}$ & 0.7 \\
\hline 6 & PRL/2*PASTOR//PBW343*2/KUKUNA/3/ROLF07/4/BERKUT//... & $0.94 *$ & $-1.11 \star$ & $1.57 \star \star$ & $-1.66^{\star \star}$ & 0.21 & $-0.64 *$ & $0.32 *$ & $0 . \mathrm{C}$ \\
\hline 7 & UP2572 & $1.83^{\star \star}$ & $2.33^{\star \star}$ & $1.12^{\star}$ & $1.45^{\star \star}$ & $3.57 * \star$ & $1.73^{\star \star}$ & $0.83^{\star *}$ & $0 . \varepsilon$ \\
\hline 8 & VL3001 & 0.61 & $2.33^{\star \star}$ & -0.21 & $-0.77^{\star}$ & $-5.36 * \star$ & $-6.33^{\star \star}$ & 0.25 & 0.2 \\
\hline 9 & NW5054 & $-0.73^{*}$ & -0.67 & -0.21 & $1.68^{* *}$ & $1.53^{* *}$ & 0.21 & $-0.49 * *$ & -0.1 \\
\hline 10 & PBW644 & 0.38 & $4.56^{\star \star}$ & 0.34 & $1.34^{\star \star}$ & $-0.95^{\star}$ & -0.30 & $-0.36^{\star}$ & 0.3 \\
\hline \multirow[t]{3}{*}{11} & C306 & $-2.28 * \star$ & $3.22^{\star \star}$ & 0.25 & $-1.66^{\star *}$ & $17.29 \star \star$ & 8.28 ** & -0.039 & 0.5 \\
\hline & S.E.(gi) & 0.41 & 0.54 & 0.49 & 0.43 & 0.51 & 0.51 & 0.15 & 0.2 \\
\hline & SE(gi-gj) & 0.58 & 0.76 & 0.69 & 0.60 & 0.72 & 0.71 & 0.21 & 0.3 \\
\hline 12 & WH1080 & $-0.59 \star \star$ & $-0.90 * *$ & -0.13 & 0.21 & $-1.98 * \star$ & $0.66^{\star \star}$ & $-0.21^{\star *}$ & $-0 .:$ \\
\hline 13 & WH1142 & 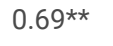 & $1.65^{\star \star *}$ & -0.22 & 0.30 & $2.56^{\star * *}$ & 0.26 & $0.33^{\star *}$ & 0.4 \\
\hline \multirow[t]{3}{*}{14} & HD3086 & -0.10 & $-0.75^{\star \star}$ & 0.35 & $-0.52^{\star}$ & $-0.58^{*}$ & $-0.93^{\star \star}$ & $-0.12^{\star \star}$ & -0 . \\
\hline & S.E.(gj) & 0.21 & 0.28 & 0.25 & 0.22 & 0.27 & 0.26 & 0.008 & 0.1 \\
\hline & SE(gi-gj) & 0.30 & 0.40 & 0.34 & 0.31 & 0.38 & 0.37 & 0.11 & 0.2 \\
\hline
\end{tabular}

*,** Significance at $5 \%$ and $1 \%$ probability levels 


\begin{tabular}{|c|c|c|c|c|c|c|c|c|c|}
\hline \multirow[t]{2}{*}{ S.N. } & \multirow[t]{2}{*}{ Parents } & \multicolumn{2}{|c|}{ Awn length (cm) } & \multicolumn{2}{|c|}{$\begin{array}{l}\text { Productive tillers/ } \\
\text { plant }\end{array}$} & \multicolumn{2}{|c|}{ Spikelets/ spike } & \multicolumn{2}{|c|}{$\begin{array}{l}\text { Flag leaf area } \\
\left(\mathrm{cm}^{2}\right)\end{array}$} \\
\hline & & E1 & E2 & E1 & E2 & E1 & E2 & E1 & E2 \\
\hline 1 & $\mathrm{BECARD/KACHU}$ & -0.25 & $-0.29 * \star$ & $2.31^{\star \star}$ & $-0.98^{* *}$ & -0.18 & $-1.05^{\star \star}$ & -0.50 & $-0.9:$ \\
\hline 2 & BOW/VEE/5/ND/VG9144//KAL/BBB/YACO/4/CHIL/6/CASKOR/3/... & $-0.42^{\star *}$ & $-0.33^{*}$ & $-3.24^{\star *}$ & $1.56^{\star \star}$ & $1.01^{\star \star}$ & $0.48^{\star \star}$ & 0.86 & 2.72 \\
\hline 3 & 92.001E7.32.5/SLVS/5/NS-732/HER/3/PRL/SARA//TSI/VEE\#5/... & 0.15 & -0.13 & $-5.02^{\star \star}$ & $-0.78^{* *}$ & 0.26 & $-1.94^{\star \star}$ & 0.48 & -0.71 \\
\hline 4 & FRANCOLIN\#1/BAJ\#1 & $0.55^{\star \star}$ & $0.60 \star \star$ & $-2.91^{\star \star}$ & $1.79 * \star$ & $-0.55^{\star}$ & $0.52^{\star \star}$ & $1.39 *$ & 1.42 \\
\hline 5 & KACHU*2//WHEAR/SOKOLL & $-0.49 * *$ & $-0.42^{\star \star}$ & $-3.69^{\star *}$ & $-1.48^{* *}$ & -0.04 & $0.96^{\star \star}$ & $6.98^{\star \star}$ & $7.2 \epsilon$ \\
\hline 6 & PRL/2*PASTOR//PBW343*2/KUKUNA/3/ROLF07/4/BERKUT//... & -0.054 & -0.02 & $2.31 * \star$ & $-1.55^{\star \star}$ & -0.04 & $-1.07 \star \star$ & $-3.75^{\star \star}$ & -2.3 \\
\hline 7 & UP2572 & $0.29 * *$ & $-0.24^{\star}$ & $2.15^{\star \star}$ & $5.34^{\star *}$ & $-0.49 * *$ & -0.24 & $-2.49 * *$ & -0.4 \\
\hline 8 & VL3001 & $0.24 * \star$ & 0.10 & 0.43 & $-0.72 * \star$ & $1.74^{\star \star}$ & $-0.93^{\star \star}$ & $1.54^{\star}$ & 0.82 \\
\hline 9 & NW5054 & $0.64 * \star$ & $1.00^{\star \star}$ & 0.43 & -0.68 ** & -0.63 ** & -0.08 & $-2.10 \star \star$ & -4.5 \\
\hline 10 & PBW644 & $-0.86^{* *}$ & $-0.53^{\star *}$ & 0.46 & $-0.98^{* *}$ & 0.121 & $1.26^{\star \star}$ & $-1.13^{*}$ & 0.04 \\
\hline \multirow[t]{3}{*}{11} & С306 & $0.22^{\star}$ & $0.26^{\star}$ & $6.76^{\star \star}$ & $-1.52^{\star *}$ & $-1.22^{* *}$ & $0.75^{\star \star}$ & $-1.29^{\star}$ & -3.3 \\
\hline & S.E.(gi) & 0.11 & 0.14 & 0.35 & 0.28 & 0.23 & 0.26 & 0.67 & $0.4 \mathrm{C}$ \\
\hline & $S E(g i-g j)$ & 0.16 & 0.19 & 0.49 & 0.40 & 0.33 & 0.36 & 0.95 & $0.6 \mathrm{c}$ \\
\hline 12 & WH1080 & $-0.16^{\star *}$ & $-0.15^{\star \star}$ & 0.497 ** & $-0.57^{\star *}$ & $0.67^{\star \star}$ & $-0.60^{\star *}$ & $-1.82^{\star \star}$ & -0.7 \\
\hline 13 & WH1142 & $0.26^{\star \star}$ & $0.23^{\star *}$ & -0.29 & $-0.97 * *$ & $1.12^{\star \star}$ & $1.13^{\star \star}$ & $2.94^{\star \star}$ & $1.8 \mathrm{C}$ \\
\hline \multirow[t]{3}{*}{14} & HD3086 & -0.10 ** & -0.08 & -0.21 & $0.67^{* \star}$ & $-0.45^{\star \star}$ & $-0.54^{\star \star}$ & $-1.11^{\star *}$ & -1.01 \\
\hline & S.E.(gj) & 0.006 & 0.07 & 0.18 & 0.15 & 0.12 & 0.13 & 0.35 & 0.25 \\
\hline & $S E(g i-g j)$ & 0.008 & 0.10 & 0.26 & 0.21 & 0.17 & 0.19 & 0.496 & 0.36 \\
\hline
\end{tabular}

*,** Significance at $5 \%$ and $1 \%$ probability levels

\begin{tabular}{|c|c|c|c|c|c|c|c|c|c|}
\hline \multirow[t]{2}{*}{ S.N. } & \multirow[t]{2}{*}{ Parents } & \multicolumn{2}{|c|}{ Grains / spike } & \multicolumn{2}{|c|}{$\begin{array}{l}\text { Grain } \\
\text { weight/spike }\end{array}$} & \multicolumn{2}{|c|}{$\begin{array}{l}\text { Biological yield / } \\
\text { plant }\end{array}$} & \multicolumn{2}{|c|}{ Grain yield/f } \\
\hline & & E1 & E2 & E1 & E2 & E1 & E2 & E1 & Ez \\
\hline 1 & $\mathrm{BECARD/KACHU}$ & $-1.92^{\star \star}$ & $-6.91 * \star$ & 0.01 & $-0.36^{\star \star}$ & $-8.56 * \star$ & $-11.76 \star \star$ & $-2.36 \star \star$ & -3 . \\
\hline 2 & BOW/VEE/5/ND/VG9144//KAL/BBB/YACO/4/CHIL/6/CASKOR/3/... & $3.44^{\star \star}$ & 0.16 & $0.47 \star \star$ & $0.18^{\star \star}$ & $-3.60 \star \star$ & $-5.58^{\star \star}$ & $-2.24^{\star \star}$ & -0 . \\
\hline 3 & 92.001E7.32.5/SLVS/5/NS-732/HER/3/PRL/SARA//TSI/VEE\#5/... & $1.70^{\star *}$ & -0.73 & 0.14 & -0.005 & $-21.15^{\star \star}$ & $1.95^{\star}$ & $-5.12^{\star \star}$ & -2 . \\
\hline 4 & FRANCOLIN\#1/BAJ\#1 & $-0.88^{* *}$ & $1.98^{* *}$ & -0.03 & -0.04 & $-19.39 * *$ & $-5.55^{\star \star}$ & 0.19 & -0 . \\
\hline 5 & KACHU*2//WHEAR/SOKOLL & $-6.32 * *$ & $8.94^{\star \star}$ & $-0.31 * *$ & $0.16^{\star \star}$ & $-9.10 * *$ & 0.58 & $-1.79 \star \star$ & -1. \\
\hline 6 & PRL/2*PASTOR//PBW343*2/KUKUNA/3/ROLF07/4/BERKUT//... & 0.16 & $-1.33^{* *}$ & -0.05 & 0.06 & $-13.43^{\star *}$ & $2.85^{\star \star}$ & $2.94^{\star \star}$ & -0 . \\
\hline 7 & UP2572 & $-9.94 * *$ & $-5.52 * \star$ & $-0.66^{* *}$ & $-0.33^{\star *}$ & $-3.47 * *$ & $22.20^{* *}$ & -0.14 & 9.1 \\
\hline 8 & VL3001 & $7.95^{\star \star}$ & $-2.37 * \star$ & $0.36^{\star \star}$ & -0.07 & $18.18^{\star \star}$ & $-3.07 * *$ & $2.98^{\star \star}$ & $1 .:$ \\
\hline 9 & NW5054 & $4.83^{\star \star}$ & $-2.20 * *$ & 0.06 & $-0.14^{\star *}$ & $-2.40 * *$ & $-5.94^{\star \star}$ & $-0.99 *$ & -0. \\
\hline 10 & PBW644 & -0.35 & $8.37^{\star \star}$ & -0.18 & $0.47 * \star$ & $18.62^{\star \star}$ & $6.35^{\star \star}$ & $3.89 \star \star$ & $2 . !$ \\
\hline \multirow[t]{3}{*}{11} & C306 & $1.33^{\star \star}$ & -0.38 & 0.18 & -0.01 & $44.31^{\star \star}$ & -2.04 ** & $2.62^{\star \star}$ & -3. \\
\hline & S.E.(gi) & 0.50 & 0.53 & 0.12 & 0.05 & 1.00 & 0.84 & 0.52 & $0:$ \\
\hline & SE(gi-gj) & 0.71 & 0.76 & 0.17 & 0.04 & 1.42 & 1.19 & 0.74 & 1.1 \\
\hline 12 & WH1080 & $-4.76^{\star \star}$ & $-1.53^{\star *}$ & -0.02 & -0.03 & $-2.83^{\star *}$ & $-2.69 \star \star *$ & $-1.14^{\star \star}$ & -1. \\
\hline 13 & WH1142 & $3.64^{\star \star}$ & $3.68^{\star \star}$ & 0.024 & $0.15^{\star \star}$ & $3.33^{\star \star}$ & -0.57 & $0.61^{*}$ & -0 . \\
\hline \multirow[t]{3}{*}{14} & HD3086 & $1.12^{\star \star}$ & $-2.15^{\star \star}$ & -0.003 & $-0.13^{\star *}$ & -0.50 & $3.26^{\star \star}$ & $0.53^{*}$ & 1.1 \\
\hline & S.E.(gj) & 0.26 & 0.28 & 0.06 & 0.03 & 0.52 & 0.44 & 0.27 & 0. \\
\hline & SE(gi-gj) & 3.71 & 0.39 & 0.09 & 0.12 & 0.74 & 0.62 & 0.38 & 1.1 \\
\hline
\end{tabular}


Table 2: SCA effect of crosses under irrigated and rainfed conditions

\begin{tabular}{|c|c|c|c|c|c|c|c|c|c|}
\hline \multirow[t]{2}{*}{ S.N. } & \multirow[t]{2}{*}{ Crosses } & \multicolumn{2}{|c|}{$\begin{array}{l}\text { Days to } 75 \% \\
\text { heading }\end{array}$} & \multicolumn{2}{|c|}{ Days to maturity } & \multicolumn{2}{|c|}{ Plant height (cm) } & \multicolumn{2}{|c|}{$\begin{array}{l}\text { Spike length } \\
(\mathrm{cm})\end{array}$} \\
\hline & & E1 & E2 & E1 & E2 & E1 & E2 & E1 & E2 \\
\hline 1 & $\mathrm{BECARD} / \mathrm{KACHU} \times \mathrm{WH} 1080$ & -0.19 & -0.10 & 1.24 & $1.79 * \star$ & $-3.47^{\star \star}$ & $-2.42^{\star \star}$ & $0.52^{\star}$ & 0.68 \\
\hline 2 & BECARD/KACHU $\times$ WH1142 & $1.20 *$ & -0.98 & 0.00 & -0.64 & $-2.23^{\star \star}$ & $1.61^{*}$ & 0.09 & -0.56 \\
\hline 3 & BECARD/KACHU × HD3086 & -1.01 & 1.08 & -1.24 & -1.15 & $5.70 * *$ & 0.81 & $-0.62^{\star}$ & -0.12 \\
\hline 4 & $\begin{array}{l}\text { BOW/VEE/5/ND/VG9144//KAL/BBB/YACO/4/CHIL/6/CASKOR/3/... } \\
\times \text { WH1080 }\end{array}$ & $-1.30 *$ & 1.01 & $-3.09 \star \star$ & -0.99 & $3.33^{\star \star}$ & 1.14 & 0.21 & 0.92 \\
\hline 5 & $\begin{array}{l}\text { BOW/VEE/5/ND/VG9144//KAL/BBB/YACO/4/CHIL/6/CASKOR/3/... } \\
\times \text { WH1142 }\end{array}$ & $1.76^{\star \star}$ & 0.46 & 1.33 & $1.25^{\star}$ & -0.07 & $5.21 \star \star$ & 0.11 & -0.35 \\
\hline 6 & $\begin{array}{l}\text { BOW/VEE/5/ND/VG9144//KAL/BBB/YACO/4/CHIL/6/CASKOR/3/... } \\
\times \text { HD3086 }\end{array}$ & -0.45 & -1.47 & $1.76^{*}$ & -0.26 & $-3.27^{\star \star}$ & $-6.35^{\star *}$ & -0.32 & -0.57 \\
\hline 7 & $\begin{array}{l}\text { 92.001E7.32.5/SLVS/5/NS-732/HER/3/PRL/SARA//TSI/VEE\#5/... × } \\
\text { WH1080 }\end{array}$ & 0.92 & 0.34 & -0.42 & -0.32 & $-3.66^{\star \star}$ & $-2.52^{\star \star}$ & -0.005 & 0.26 \\
\hline 8 & $\begin{array}{l}\text { 92.001E7.32.5/SLVS/5/NS-732/HER/3/PRL/SARA//TSI/VEE\#5/... × } \\
\text { WH1142 }\end{array}$ & 0.98 & -1.54 & 1.33 & 0.25 & $3.55^{\star \star}$ & $-1.54^{\star \star}$ & 0.40 & -0.23 \\
\hline 9 & $\begin{array}{l}\text { 92.001E7.32.5/SLVS/5/NS-732/HER/3/PRL/SARA//TSI/VEE\#5/... × } \\
\text { HD3086 }\end{array}$ & $-1.90 \star \star$ & 1.19 & -0.91 & 0.07 & 0.11 & $4.07 * \star$ & -0.40 & -0.03 \\
\hline 10 & FRANCOLIN\#1/BAJ\# 1 × WH1080 & 0.25 & 0.343 & -0.42 & $2.12^{\star \star}$ & 1.24 & $2.96^{\star \star}$ & -0.31 & 0.13 \\
\hline 11 & FRANCOLIN\#1/BAJ\# $1 \times$ WH1142 & -0.02 & $-3.87^{\star \star}$ & 1.00 & $-2.30 * \star$ & -0.22 & $1.99 \star \star$ & 0.10 & -0.07 \\
\hline 12 & FRANCOLIN\#1/BAJ\#1 1 HD3086 & -0.23 & $3.53^{\star \star}$ & -0.58 & 0.18 & -1.02 & $-4.95^{\star \star}$ & 0.21 & -0.06 \\
\hline 13 & $\mathrm{KACHU} * 2 / /$ WHEAR/SOKOLL $\times$ WH1080 & $-4.08^{\star *}$ & $-1.99 *$ & -0.76 & $-2.66 * \star$ & $3.78^{\star *}$ & $4.16^{\star \star}$ & 0.31 & -0.28 \\
\hline 14 & $\mathrm{KACHU}$ *2//WHEAR/SOKOLL $\times$ WH1142 & $-1.69 * *$ & $4.80^{\star \star}$ & -1.33 & $2.92^{\star \star}$ & $5.07 * \star$ & $-4.44^{\star \star}$ & -0.28 & -0.21 \\
\hline 15 & KACHU*2//WHEAR/SOKOLL × HD3086 & $5.77^{\star \star}$ & $-2.81 * \star$ & $2.09 * *$ & -0.26 & $-8.84^{* *}$ & 0.27 & -0.02 & 0.491 \\
\hline 16 & $\begin{array}{l}\text { PRL/2*PASTOR//PBW343*2/KUKUNA/3/ROLF07/4/BERKUT//... × } \\
\text { WH1080 }\end{array}$ & $1.70 \star \star$ & -0.43 & -0.20 & 1.23 & -0.48 & $2.78^{\star \star}$ & $-0.61^{\star}$ & $0.15^{\circ}$ \\
\hline 17 & $\begin{array}{l}\text { PRL/2*PASTOR//PBW343*2/KUKUNA/3/ROLF07/4/BERKUT//... × } \\
\text { WH1142 }\end{array}$ & 1.09 & -1.31 & -0.78 & -0.53 & $-1.54 \star \star$ & -1.35 & -0.12 & -0.21 \\
\hline 18 & $\begin{array}{l}\text { PRL/2*PASTOR//PBW343*2/KUKUNA/3/ROLF07/4/BERKUT //... × } \\
\text { HD3086 }\end{array}$ & $-2.79 \star \star$ & $1.75^{\star \star}$ & 0.98 & -0.71 & $2.01^{\star}$ & -1.43 & $0.73^{\star}$ & 0.06 \\
\hline 19 & UP2572 × WH1080 & 1.14 & 1.45 & -0.09 & -0.55 & $-2.55^{\star \star}$ & $-6.27 \star \star$ & 0.30 & -0.77 \\
\hline 20 & UP2572 × WH1142 & $-2.80 \star \star$ & -0.42 & $-1.67 \star \star$ & -1.30 & $-1.99 *$ & $3.88^{* \star}$ & $-0.57^{\star}$ & 0.09 \\
\hline 21 & UP2572 × HD3086 & $1.66^{*}$ & -1.03 & $1.76^{\star \star}$ & $1.85^{\star \star}$ & $4.54^{\star \star}$ & $2.38^{\star \star}$ & 0.27 & -0.10 \\
\hline 22 & VL3001 × WH1080 & 0.36 & $-2.88 * \star$ & $1.24^{\star}$ & $1.68^{\star \star}$ & $1.59 *$ & $3.50 * \star$ & 0.01 & -0.79 \\
\hline 23 & VL3001 × WH1142 & 0.76 & $5.24^{\star \star}$ & 0.67 & $-2.08^{* *}$ & $-2.67 \star \star$ & -1.01 & -0.20 & 0.34 \\
\hline 24 & VL3001 × HD3086 & -1.12 & $-2.36^{\star \star}$ & $-1.91^{\star \star}$ & 0.40 & 1.08 & $-2.49 \star \star$ & 0.21 & -0.26 \\
\hline 25 & NW5054 × WH1080 & -0.30 & $4.12^{\star \star}$ & -0.09 & $-4.10 * \star$ & $1.54^{\star}$ & -0.96 & 0.15 & -0.73 \\
\hline 26 & NW5054 × WH1142 & -0.24 & -0.42 & $1.00 *$ & $2.14^{\star \star}$ & $-1.62^{\star}$ & $2.74^{\star \star}$ & $-0.44^{\star}$ & -0.20 \\
\hline 27 & NW5054 × HD3086 & 0.55 & $-3.70 * \star$ & -0.91 & $1.96^{\star}$ & 0.08 & $-1.78^{\star}$ & 0.29 & $0.93^{2}$ \\
\hline 28 & PBW644 × WH1080 & $1.92^{\star \star}$ & $1.90^{\star}$ & $3.35^{\star \star *}$ & 0.90 & $-2.48 * \star$ & $-1.61^{*}$ & -0.37 & -0.58 \\
\hline 29 & PBW644 × WH1142 & $-1.69 * \star$ & -0.31 & $-1.89 * \star$ & 0.81 & 0.03 & $-5.80 \star \star$ & 0.26 & 0.43 \\
\hline 30 & PBW644 × HD3086 & -0.23 & $-1.59 *$ & $-1.46 * \star$ & $-1.71^{\star}$ & $2.45^{\star \star}$ & 7.41 ** & 0.11 & 0.15 \\
\hline 31 & C306 × WH1080 & -0.41 & $-3.77 * \star$ & -0.76 & 0.90 & 1.16 & -0.77 & -0.19 & -0.41 \\
\hline 32 & C306 × WH1142 & 0.65 & $-1.65^{\star \star}$ & 0.33 & -0.53 & $1.68^{*}$ & -1.29 & $0.66^{\star *}$ & $0.99^{\circ}$ \\
\hline 33 & C306 $\times$ HD3086 & -0.23 & $5.41^{\star \star}$ & 0.42 & -0.37 & $-2.84^{\star *}$ & $2.07 *$ & $-0.47^{\star}$ & -0.59 \\
\hline
\end{tabular}




\begin{tabular}{|c|c|c|c|c|c|c|c|c|c|}
\hline \multirow[t]{2}{*}{ S.N. } & \multirow[t]{2}{*}{ Crosses } & \multicolumn{2}{|c|}{ Awn length (cm) } & \multicolumn{2}{|c|}{$\begin{array}{l}\text { Productive } \\
\text { tillers/plant }\end{array}$} & \multicolumn{2}{|c|}{ Spikelets/spike } & \multicolumn{2}{|c|}{$\begin{array}{l}\text { Flag leaf area } \\
\left(\mathrm{cm}^{2}\right)\end{array}$} \\
\hline & & E1 & E2 & E1 & E2 & E1 & E2 & E1 & E2 \\
\hline 1 & $\mathrm{BECARD} / \mathrm{KACHU} \times \mathrm{WH} 1080$ & $0.59 * \star$ & $0.43^{*}$ & $3.61^{\star \star}$ & $1.32^{\star \star}$ & 0.53 & -0.18 & $-2.41^{\star}$ & -1.08 \\
\hline 2 & BECARD/KACHU $\times$ WH1142 & $-0.72^{\star \star}$ & -0.25 & $-2.27 \star \star$ & -0.65 & $0.95^{\star}$ & -0.08 & 1.73 & -1.19 \\
\hline 3 & $\mathrm{BECARD} / \mathrm{KACHU} \times \mathrm{HD} 3086$ & 0.14 & -0.18 & $-1.35^{\star}$ & -0.67 & $-1.48^{\star \star}$ & 0.26 & 0.68 & $2.27^{\star}$ \\
\hline 4 & $\begin{array}{l}\text { BOW/VEE/5/ND/VG9144//KAL/BBB/YACO/4/CHIL/6/CASKOR/3/... } \\
\times \text { WH1080 }\end{array}$ & $-0.41^{\star}$ & -0.36 & 0.17 & $3.41 * \star$ & 0.008 & 0.34 & 1.34 & $3.17^{*}$ \\
\hline 5 & $\begin{array}{l}\text { BOW/VEE/5/ND/VG9144//KAL/BBB/YACO/4/CHIL/6/CASKOR/3/... } \\
\times \text { WH1142 }\end{array}$ & $0.44^{*}$ & 0.20 & 0.29 & $-2.95^{\star \star}$ & -0.24 & $1.35^{\star \star}$ & $-5.19 * *$ & -2.90 \\
\hline 6 & $\begin{array}{l}\text { BOW/VEE/5/ND/VG9144//KAL/BBB/YACO/4/CHIL/6/CASKOR/3/... } \\
\times \text { HD3086 }\end{array}$ & -0.03 & 0.16 & -0.46 & -0.46 & 0.23 & $-1.72^{\star \star}$ & $3.85^{\star \star}$ & -0.28 \\
\hline 7 & $\begin{array}{l}\text { 92.001E7.32.5/SLVS/5/NS-732/HER/3/PRL/SARA//TSI/VEE\#5/... × } \\
\text { WH1080 }\end{array}$ & $0.76^{\star \star}$ & -0.36 & -0.72 & -0.13 & $-0.81^{\star}$ & 0.65 & 0.98 & -2.98 \\
\hline 8 & $\begin{array}{l}\text { 92.001E7.32.5/SLVS/5/NS-732/HER/3/PRL/SARA//TSI/VEE\#5/... } \\
\text { WH1142 }\end{array}$ & $0.71^{\star \star}$ & 0.31 & 0.73 & -0.75 & $1.39 \star \star$ & $-1.02^{\star}$ & $-5.03 * \star$ & $1.65^{\star}$ \\
\hline 9 & $\begin{array}{l}\text { 92.001E7.32.5/SLVS/5/NS-732/HER/3/PRL/SARA//TSI/VEE\#5/... × } \\
\text { HD3086 }\end{array}$ & 0.05 & 0.05 & -0.01 & 0.88 & -0.58 & 0.37 & $4.05^{\star \star}$ & 1.34 \\
\hline 10 & FRANCOLIN\#1/BAJ\#1 × WH1080 & -0.21 & 0.08 & -0.83 & $-1.21^{\star \star}$ & -0.66 & -0.26 & -0.84 & -1.30 \\
\hline 11 & FRANCOLIN\#1/BAJ\# $1 \times$ WH1142 & -0.13 & -0.04 & -0.38 & $2.07 * \star$ & -0.46 & $-0.92^{\star}$ & -0.66 & -0.64 \\
\hline 12 & FRANCOLIN\#1/BAJ\#1 × HD3086 & $0.34 *$ & -0.04 & $1.21 *$ & $-0.86^{\star}$ & $1.12^{\star \star}$ & $1.18^{\star \star}$ & $1.49 *$ & $1.94^{*}$ \\
\hline 13 & KACHU*2//WHEAR/SOKOLL $\times$ WH1080 & $0.88 * \star$ & -0.06 & $2.61 \star \star$ & 0.65 & $2.40 * \star$ & 0.30 & $-1.76^{\star}$ & -1.85 \\
\hline 14 & KACHU*2//WHEAR/SOKOLL $\times$ WH1142 & $-0.48 * \star$ & -0.36 & -0.60 & -0.15 & 0.36 & 0.68 & -4.16 ** & -2.53 \\
\hline 15 & KACHU*2//WHEAR/SOKOLL $\times$ HD3086 & -0.40 & $0.43^{*}$ & $-2.01 * *$ & -0.50 & $-2.73^{\star \star}$ & $-0.98^{*}$ & $5.93^{\star \star}$ & $4.37^{\star}$ \\
\hline 16 & $\begin{array}{l}\text { PRL/2*PASTOR//PBW343*2/KUKUNA/3/ROLF07/4/BERKUT//... × } \\
\text { WH1080 }\end{array}$ & -0.19 & 0.08 & 0.28 & $0.99 *$ & $-0.74 * \star$ & 0.23 & -0.85 & 0.68 \\
\hline 17 & $\begin{array}{l}\text { PRL/2*PASTOR//PBW343*2/KUKUNA/3/ROLF07/4/BERKUT//... × } \\
\text { WH1142 }\end{array}$ & -0.09 & 0.096 & 0.73 & $1.11^{\star}$ & $0.80 \star \star$ & 0.16 & $2.45^{\star}$ & 0.47 \\
\hline 18 & $\begin{array}{l}\text { PRL/2*PASTOR//PBW343*2/KUKUNA/3/ROLF07/4/BERKUT//... × } \\
\text { HD3086 }\end{array}$ & 0.27 & -0.17 & $-1.01^{\star}$ & $-2.10 * \star$ & -0.06 & -0.39 & -1.60 & -1.15 \\
\hline 19 & UP2572 × WH1080 & -0.17 & $0.496 *$ & -0.22 & $-3.75^{\star \star}$ & -0.07 & 0.10 & $3.95^{\star \star}$ & -0.26 \\
\hline 20 & UP2572 × WH1142 & 0.13 & -0.37 & -0.27 & $-2.13^{\star \star}$ & $-2.31 * \star$ & $-1.78^{\star \star}$ & -0.57 & $2.24^{*}$ \\
\hline 21 & UP2572 × HD3086 & 0.05 & -0.12 & -0.49 & $5.88 * \star$ & $2.38^{\star \star}$ & $1.68^{\star \star}$ & $-3.38 * \star$ & -1.98 \\
\hline 22 & VL3001 × WH1080 & $0.38^{*}$ & 0.04 & $1.17 *$ & $0.97 *$ & $-0.95^{\star}$ & -0.22 & -1.65 & $2.82^{\star}$ \\
\hline 23 & VL3001 × WH1142 & -0.21 & -0.02 & -0.05 & 0.58 & -0.53 & 0.16 & $5.30 * \star$ & $1.59 *$ \\
\hline 24 & VL3001 × HD3086 & -0.17 & -0.02 & $-1.12^{*}$ & $-1.56^{\star \star}$ & $1.49 \star \star$ & -0.06 & $-3.65^{\star \star}$ & -4.40 \\
\hline 25 & NW5054 × WH1080 & 0.07 & -0.35 & $-4.50 \star \star$ & -0.57 & 0.30 & 0.63 & $5.23^{\star \star}$ & 1.19 \\
\hline 26 & NW5054 × WH1142 & -0.22 & 0.06 & $3.29 \star \star$ & 0.04 & $-0.83^{*}$ & $-1.10 \star \star$ & $-2.13^{\star}$ & -1.85 \\
\hline 27 & NW5054 × HD3086 & 0.15 & 0.29 & $1.21 *$ & 0.53 & 0.53 & 0.46 & -3.10 ** & 0.66 \\
\hline 28 & PBW644 × WH1080 & 0.28 & 0.27 & 0.91 & $-1.18^{\star *}$ & 0.45 & $-0.88^{*}$ & 0.62 & 0.76 \\
\hline 29 & PBW644 × WH1142 & 0.13 & 0.09 & $-1.75^{\star \star}$ & 0.10 & 0.43 & $1.39 \star \star$ & 1.66 & $1.95^{\star}$ \\
\hline 30 & PBW644 × HD3086 & $-0.42^{*}$ & -0.36 & 0.84 & 1.08 & $-0.88^{*}$ & -0.50 & $-2.28^{\star}$ & -2.72 \\
\hline 31 & C306 × WH1080 & $-0.47^{\star}$ & -0.26 & $-2.50 * \star$ & -0.51 & -0.44 & -0.70 & $-4.62 * *$ & -1.15 \\
\hline 32 & C306 × WH1142 & $0.45^{\star}$ & 0.27 & 0.29 & $2.72^{\star \star}$ & 0.43 & $1.13^{\star \star}$ & $6.59 * \star$ & 1.21 \\
\hline 33 & C306 × HD3086 & 0.02 & -0.02 & $2.21^{\star \star}$ & $-2.21 * \star$ & 0.007 & -0.42 & $-1.96^{\star}$ & -0.05 \\
\hline
\end{tabular}




\begin{tabular}{|c|c|c|c|c|c|c|c|c|}
\hline \multirow[t]{2}{*}{ S.N. } & \multirow[t]{2}{*}{ Crosses } & \multicolumn{2}{|c|}{ Grains/spike } & \multicolumn{2}{|c|}{$\begin{array}{l}\text { Grain } \\
\text { weight/spike }\end{array}$} & \multicolumn{2}{|c|}{$\begin{array}{l}\text { Biological } \\
\text { yield/plant }\end{array}$} & \multirow{2}{*}{$\begin{array}{l}\text { Grain yiel } \\
\text { E1 }\end{array}$} \\
\hline & & E1 & E2 & E1 & E2 & E1 & E2 & \\
\hline 1 & $\mathrm{BECARD} / \mathrm{KACHU} \times \mathrm{WH} 1080$ & $7.04 * \star$ & 0.81 & 0.25 & $0.45^{\star \star}$ & $6.71^{\star \star}$ & -1.31 & $1.58^{*}$ \\
\hline 2 & BECARD/KACHU $\times$ WH1142 & $-9.12^{\star \star}$ & 1.09 & $-0.49 \star \star$ & $-0.32^{\star *}$ & $-2.94 \star \star$ & 0.95 & $3.55^{\star *}$ \\
\hline 3 & BECARD/KACHU $\times$ HD3086 & $2.08^{\star \star}$ & $-9.90 * \star$ & 0.24 & -0.13 & $-3.78^{\star \star}$ & 0.36 & $-5.13^{\star \star}$ \\
\hline 4 & $\begin{array}{l}\text { BOW/VEE/5/ND/VG9144//KAL/BBB/YACO/4/CHIL/6/CASKOR/3/... } \\
\times \text { WH1080 }\end{array}$ & $-1.54^{\star}$ & $4.56^{\star *}$ & 0.003 & $0.26^{* *}$ & $13.82^{\star \star}$ & $6.995^{\star \star}$ & -3.50 ** \\
\hline 5 & $\begin{array}{l}\text { BOW/VEE/5/ND/VG9144//KAL/BBB/YACO/4/CHIL/6/CASKOR/3/... } \\
\times \text { WH1142 }\end{array}$ & $4.57^{\star \star}$ & 0.63 & -0.08 & -0.01 & $-7.11 \star \star$ & -11.78 ** & -0.80 \\
\hline 6 & $\begin{array}{l}\text { BOW/VEE/5/ND/VG9144//KAL/BBB/YACO/4/CHIL/6/CASKOR/3/... } \\
\times \text { HD3086 }\end{array}$ & $-3.03^{\star \star}$ & -5.198 ** & 0.08 & $-0.25^{\star \star}$ & $-6.71 * \star$ & $4.79 * \star$ & $4.29 * *$ \\
\hline 7 & $\begin{array}{l}\text { 92.001E7.32.5/SLVS/5/NS-732/HER/3/PRL/SARA//TSI/VEE\#5/... × } \\
\text { WH1080 }\end{array}$ & $7.09 * *$ & $-2.61^{\star \star}$ & 0.21 & $-0.23^{\star \star}$ & $8.11^{\star *}$ & $3.10 *$ & 0.86 \\
\hline 8 & $\begin{array}{l}\text { 92.001E7.32.5/SLVS/5/NS-732/HER/3/PRL/SARA//TSI/VEE\#5/... } \times \\
\text { WH1142 }\end{array}$ & $-8.47 \star \star$ & $-5.86^{\star \star}$ & -0.25 & -0.11 & $-10.27 \star \star$ & $3.79 * \star$ & -0.12 \\
\hline 9 & $\begin{array}{l}\text { 92.001E7.32.5/SLVS/5/NS-732/HER/3/PRL/SARA//TSI/VEE\#5/... × } \\
\text { HD3086 }\end{array}$ & 1.38 & $8.46^{\star \star}$ & 0.03 & $0.34^{\star \star}$ & 2.17 & $-6.89 * \star$ & -0.74 \\
\hline 10 & FRANCOLIN\#1/BAJ\#1 × WH1080 & $1.42^{*}$ & $-5.59 * \star$ & 0.10 & -0.02 & $-13.06^{\star \star}$ & 5.41 ** & 0.33 \\
\hline 11 & FRANCOLIN\#1/BAJ\#1 × WH1142 & 0.95 & -1.22 & -0.05 & $-0.22^{\star \star}$ & 1.03 & $-7.31 * \star$ & $-1.80 *$ \\
\hline 12 & FRANCOLIN\#1/BAJ\#1 × HD3086 & -0.37 & $6.81^{\star \star}$ & -0.06 & $0.24^{\star \star}$ & $12.03^{\star \star}$ & 1.89 & 1.47 \\
\hline 13 & $\mathrm{KACHU} 2 / / \mathrm{WHEAR} / \mathrm{SOKOLL} \times \mathrm{WH} 1080$ & -0.77 & $-10.76^{\star \star}$ & -0.25 & -0.298 ** & $7.04 * \star$ & $-8.39 * \star$ & $7.65^{\star \star}$ \\
\hline 14 & KACHU*2//WHEAR/SOKOLL $\times$ WH1142 & $10.03^{\star *}$ & $-5.26 \star \star$ & $0.42^{*}$ & $-0.23^{\star \star}$ & $-5.62^{\star \star}$ & 0.60 & $-1.59 *$ \\
\hline 15 & $\mathrm{KACHU} * 2 / /$ WHEAR/SOKOLL $\times$ HD3086 & $-9.26 * \star$ & $16.02^{\star \star}$ & -0.18 & $0.53^{\star *}$ & -1.41 & $7.79 * \star$ & $-6.07 \star \star$ \\
\hline 16 & $\begin{array}{l}\text { PRL/2*PASTOR//PBW343*2/KUKUNA/3/ROLF07/4/BERKUT//... × } \\
\text { WH1080 }\end{array}$ & $-7.20 * \star$ & $2.79 \star \star$ & 0.24 & 0.07 & $-8.42^{\star \star}$ & $8.40 * \star$ & $-3.23^{\star \star}$ \\
\hline 17 & $\begin{array}{l}\text { PRL/2*PASTOR//PBW343*2/KUKUNA/3/ROLF07/4/BERKUT//... × } \\
\text { WH1142 }\end{array}$ & -1.22 & $8.81 * \star$ & -0.29 & $0.41^{\star *}$ & -0.46 & $-6.03^{\star *}$ & $3.63^{\star *}$ \\
\hline 18 & $\begin{array}{l}\text { PRL/2*PASTOR//PBW343*2/KUKUNA/3/ROLF07/4/BERKUT//... × } \\
\text { HD3086 }\end{array}$ & $8.42^{\star \star}$ & $-11.60 * *$ & 0.05 & $-0.48^{\star \star}$ & $8.88^{\star \star}$ & -2.37 & -0.40 \\
\hline 19 & UP2572 × WH1080 & $2.40 * \star$ & $9.81^{\star *}$ & 0.009 & $0.66^{\star \star}$ & $7.67 * \star$ & $-11.96^{\star \star}$ & $-5.84^{\star \star}$ \\
\hline 20 & UP2572 × WH1142 & $-8.08^{\star \star}$ & $-5.90 * \star$ & -0.13 & $-0.42^{\star \star}$ & $21.85^{\star \star}$ & $7.81^{\star \star}$ & $6.46^{* *}$ \\
\hline 21 & UP2572 × HD3086 & $5.68^{\star *}$ & $-3.91^{\star \star}$ & 0.11 & -0.24 *夫 & $-29.52^{\star \star}$ & $4.15^{\star \star}$ & -0.62 \\
\hline 22 & VL3001 × WH1080 & $-8.99 * \star$ & $8.66^{\star \star}$ & $-0.66 \star \star$ & -0.04 & 13.11 *夫 & $10.93^{\star \star}$ & $4.86^{\star \star}$ \\
\hline 23 & VL3001 × WH1142 & $3.11^{* *}$ & $-8.12^{\star \star}$ & $0.43^{*}$ & -0.06 & $-10.92^{\star \star}$ & $-2.91 *$ & $-8.33^{\star \star}$ \\
\hline 24 & VL3001 × HD3086 & $5.88^{\star \star}$ & -0.55 & 0.22 & 0.10 & -2.20 & $-8.02^{\star *}$ & $3.47^{* *}$ \\
\hline 25 & NW5054 × WH1080 & $-3.87 \star \star$ & $-3.49 * \star$ & -0.07 & 0.07 & 2.39 & $-8.29 \star \star$ & 0.37 \\
\hline 26 & NW5054 × WH1142 & $1.74^{*}$ & $-1.56^{*}$ & 0.28 & -0.10 & $4.97^{\star \star}$ & $5.08^{\star \star}$ & $-5.44^{\star \star}$ \\
\hline 27 & NW5054 × HD3086 & $2.13^{\star \star}$ & 5.05 & -0.21 & 0.03 & $-7.37 * \star$ & $3.20 \star \star$ & $5.07 * \star$ \\
\hline 28 & PBW644 × WH1080 & $3.64^{\star *}$ & -9.31 & 0.19 & $-0.72^{\star \star}$ & $-13.30 * \star$ & 3.21 ** & -0.43 \\
\hline 29 & PBW644 × WH1142 & $-1.74^{*}$ & 7.86 & -0.22 & $0.56^{\star \star}$ & 2.65 & $-2.93^{*}$ & $4.10 * *$ \\
\hline 30 & PBW644 × HD3086 & $-1.90 *$ & 1.44 & 0.02 & $0.16^{*}$ & $10.65^{\star \star}$ & -0.28 & $-3.67 * \star$ \\
\hline 31 & C306 × WH1080 & 0.77 & -2.88 & -0.04 & $-0.196^{\star}$ & $-24.08^{\star \star}$ & $-8.11 * \star$ & $-2.65^{\star \star}$ \\
\hline 32 & C306 × WH1142 & 8.24 * & 9.51 & $0.36^{*}$ & $0.51^{\star \star}$ & $6.82 * \star$ & $12.73^{\star \star}$ & 0.32 \\
\hline 33 & C306 $\times$ HD3086 & $-9.00 * \star$ & -6.63 & -0.32 & -0.31 ** & $17.27^{\star \star}$ & $-4.61^{\star \star}$ & $2.33^{* *}$ \\
\hline
\end{tabular}

*,* significance at $5 \%$ and $1 \%$ probability level 